九州大学学術情報リポジトリ

Kyushu University Institutional Repository

\title{
A revision of the subgenus Euandrena of the genus Andrena of Eastern Asia (Hymenoptera: Apoidea: Andrenidae)
}

Xu, Huan- $\mathrm{li}$

Department of Entomology, College of Agriculture and Biotechnology, China Agricultural University

Tadauchi, 0samu

Entomological Laboratory, Faculty of Agriculture, Kyushu University

https://doi.org/10.5109/25400

出版情報: ESAKIA. 52，pp.77-90，2012-03-27. Entomological Laboratory，Faculty of Agriculture， Kyushu University

バージョン：

権利関係 : 


\title{
A Revision of the Subgenus Euandrena of the Genus Andrena of Eastern Asia (Hymenoptera: Apoidea: Andrenidae)
}

\author{
XU Huan-li ${ }^{1)}$ and Osamu TAdauchi ${ }^{2)}$ \\ 1) Department of Entomology, College of Agriculture and Biotechnology, China Agricultural \\ University, Beijing 100193, China \\ 2) Entomological Laboratory, Faculty of Agriculture, Kyushu University, Fukuoka 812-8581, Japan
}

\begin{abstract}
The subgenus Euandrena of the genus Andrena from eastern Asia is revised and 14 species are recognized. Six new species, $A$. (Euandrena) sichuana n. sp., A. (Euandrena) communisella n. sp., A. (Euandrena) tomuerna n. sp., Andrena (Euandrena) carbointegra n. sp., A. (Euandrena) subruficrus $\mathrm{n}$. sp., and A. (Euandrena) yamagishii n. sp. are described, Andrena (Euandrena) tateyamana Tamasawa et Hirashima, A. (Euandrena) bicolor Fabricius and A. (Euandrena) ruficrus rabicrus Hirashima are recorded from China for the first time. A key to East Asian females of Euandrena is given.
\end{abstract}

Key words: taxonomy, Hymenoptera, Andrenidae, Andrena (Eundrena), revision, eastern Asia, new species.

\section{Introduction}

The holarctic subgenus Euandrena was erected by Hedicke in 1933. It is characterized by the pronotum without humeral angle and ridge, facial fovea narrow in female, propodeal corbicula moderately developed without anterior fringes, tibial scopal hairs long, simple, metasomal terga impunctate or weakly punctate with apical hair bands or not, male clypeus black, first flagellar segment long, sterna with weak subapical fimbriae or not. In Europe, Warncke (1968) included 15 species in this subgenus, and he described 16 new species later. Tadauchi and Hirashima (1987) gave a synopsis and a key to six species of Euandrena from Japan. In Russian Far East, Osytshnjuk (1995) gave a key to five species in this subgenus. Tadauchi et. al (2005) described Andrena (Euandrena) almas from Xinjiang, China. Scheuchl (2005) described two new species, Andrena (Euandrena) euphorbiacea and A. (Euandrena) humlaensis from China and Nepal, respectively, Tadauchi and Matsumura (2007) described A. (Euandrena) kathmanduensis from Nepal. Now, the holarctic Euandrena is represented by 54 species in the Palaearctic region and 21 species in the Nearctic region (Ascher and Pickering, 2011). In this study, we examined species deposited in the Institute of Zoology, Academia Sinica and the Entomological Laboratory, Kyushu University, and recognized 14 species of Euandrena from eastern Asia. We synonymized A. subopercula Wu with $A$. opercula Wu. Andrena (Euandrena) tateyamana Tamasawa et Hirashima, A. (Euandrena) bicolor Fabricius and A. (Euandrena) ruficrus rabicrus Hirashima are recorded from China for the first time. We described six new species, A. (Euandrena) sichuana $\mathrm{n}$. sp., A. (Euandrena) communisella n. sp,, Andrena (Euandrena) carbointegra n. sp., A. (Euandrena) tomuerna n. sp. and A. (Euandrena) yamagishii n. sp. and $A$. (Euandrena) subruficrus n. sp. from China. Andrena (Euandrena) takachihoi Hirashima and Andrena (Euandrena) togashii Tadauchi et Hirashima are transferred to the subgenus Ptilandrena. Five species of $A$. (Euandrena) fulvida Schenck, A. (Euandrena) mutini Osytshnjuk, A. (Euandrena) khabarovi Osytshnjuk, A. (Euandrena) orientaliella Osytshnjuk from Russian Far East and A. (Euandrena) yangi Dubitzky from Taiwan are excluded from this study because we have no materials at hands. A key to East Asian females of Euandrena is given. Specimens were borrowed from the Institute of Zoology, Academia Sinica (Beijing) and the Entomological

E-mail: hanabati@cau.edu.cn 
Laboratory, Kyushu University (Fukuoka). The holotypes and some paratypes will be deposited in the Institute of Zoology, Academia Sinica, Beijing, and part of the paratypes will be deposited in the Entomological Laboratory, Kyushu University, Fukuoka.

\section{Subgenus Euandrena Hedicke}

Euandrena Hedicke, 1933, Mitt. Zool. Mus. Berlin, 19: 212-213; Warncke, 1968, Mem. Est. Mus. Zool. Univ. Coimbra, (307): 80-81; LaBerge, 1975, Trans. Amer. ent. Soc., 101: 372-373. Type species: Andrena bicolor Fabricius, 1775, by original designation.

Xanthandrena Lanham, 1949, Univ. California Publ. Ent., 8: 218. Type species: Andrena auricoma Smith, 1879, by original designation.

Geandrena LaBerge, 1964, Bull. Univ. Nebraska St. Mus., 4: 313-314. Type species: Andrena caerulea Smith, 1879, by original designation.

Diagnosis: Small to medium-sized bees; facial quadrangle broader than long or elongate; facial fovea narrow, short, just extending to below a line at lower margin of antennal fossae or not; malar space linear or short; genal area as broad as or broader than eye, not angulate posteriorly; pronotum without humeral angle and ridge; propodeal corbicula moderately developed, without anterior fringes; tibial scopal hairs long, simple; three submarginal cells present; metasomal terga impunctate or weakly punctate, with apical hair bands or not. Male clypeus black, first flagellar segment long, sterna with weak subapical fimbriae or not.

\section{Key to species of the subgenus Euandrena in eastern Asia Female}

1. Metasomal terga 1-3 red partly 2

- Metasomal terga entirely black 4

2. Clypeus and mesepisternum with brown hairs; facial quadrangle slightly longer than broad ....opercula $\mathrm{Wu}$

- Clypeus and mesepisternum with fulvous hairs; facial quadrangle as broad as long

3. Clypeus sparsely punctate; first flagellar segment as long as the next two segments together; mesoscutum and scutellum tessellate with weak punctures; metasomal terga with narrow red maculae, surface densely tessellate sichuana $\mathrm{n}$. sp.

- Clypeus coarsely punctate; first flagellar segment longer than the next two segments together; mesoscutum and scutellum shinier with fine PP; metasomal terga broadly red marking, surface weakly tessellate, shiny ......................................... communisella $\mathrm{n}$. sp.

4. Clypeus coarsely punctate with raised median impunctate line; mandibles short, not crossed; facial fovea long, exceeding below a line at lower margin of antennal fossae, length about $8 \mathrm{~mm}$ tomuerna $\mathrm{n}$. sp.

- Clypeus coarsely or finely punctate without raised median impunctate line; mandibles long, crossed; if not crossed, then hind tibia ferruginous or brown integument; facial fovea short, extending a line at lower margin of antennal fossae ............................... 5

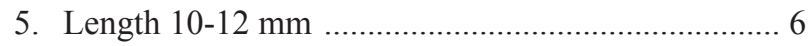

- Length 7-9 mm ....................................................... 8

6. Clypeus sparsely punctate, with median indistinct, tessellate impunctate space; metasomal terga with interrupted hair bands

tateyamana Tamasawa et Hirashima

- Clypeus densely to coarsely punctate; metasomal terga with abundant hairs or scanty hairs ................. 7

7. Clypeus coarsely punctate, surface dulling; head and thorax mainly with brown hairs; first flagellar segment longer than the next two segments together; metasomal terga scanty hairs ......... carbointegralla, n. sp.

- Clypeus densely punctate, surface weakly shiny; head with brown hairs; first flagellar segment as long as the next two segments together; dorsal thorax with reddish yellow hairs; metasomal terga with abundant brown hairs bicolor Fabricius

8. Facial quadrangle longer than broad 9

- Facial quadrangle as long as broad ........................ 11

9. Process of labrum rectangle, emarginate; clypeus shiny at apical half; tibial scopal hairs loose

hoffmanni Strand

- Process of labrum trapezoidal, entire; clypeus shiny at apical 2/3; tibial scopal hairs compact 10

10. Malar space about $1 / 5$ time as long as width of basal mandible; metasomal terga with apical fasciae distinct ............................................... hebes Pérez

- Malar space about 1/6 time as long as width of basal mandible; metasomal terga with apical fasciae weak luridiloma Strand

11. Mesoscutum coarsely punctate, roughened surface; metasomal terga densely tessellate without puncture yamagishii $\mathrm{n} . \mathrm{sp}$.

- Metasomal terga sparsely punctate, not roughened, metasomal terga weakly tessellate, shiny .............. 12

12. Hind tibia black with white tibial scopal hairs; metasomal terga weakly punctate at basal tergal $2 / 3$; mesoscutum broadly smooth and shiny with minute punctures ................................... subshawella Strand

- Hind tibia ferruginous with golden tibial scopal hairs; 
metasomal terga impunctate; mesoscutum densely tessellate 13

13. Clypeus with small PP separated by 1-2 punctures width, PP sparser medially; process of labrum broad; mandibles crossed at mid-labrum

ruficrus rubicrus Hirashima

- Clypeus with small PP separated by 0.5-1 puncture width; process of labrum narrow; mandibles just meet at mid-labrum subruficrus n. sp.

\section{Andrena (Euandrena) opercula Wu}

Andrena (Taeniandrena) opercula Wu, 1982, Insects Xizang, Vol 2, 381 [female \& male, China].

Andrena (Taeniandrena) subopercula $\mathrm{Wu}, 1982$, Insects Xizang, Vol 2, 382 [female, China]. New synonymy

Female (redescription of the type): BL 8.5-10.7 mm, WL 7.5-8.0 mm ( $\mathrm{n}=2)$.

Color: Flagellum dark reddish brown beneath; mandible with apical third or more reddened; wing membranes hyaline, veins and pterostigma reddish brown; tibial spurs testaceous; metasomal terga 1 with apical area, tergum 2 or 3 reddish, posterior margins of terga red to dark red.

Pubescence: Hairs on head dense, brown to black except vertex mixed with dull white; those on clypeus 200-400 $\mu$, brown; those on antennal area and genal area black; those on vertex $400 \mu$; facial fovea black. Hairs on dorsum of thorax dull white, dark brown laterally and ventrally; those on mesoscutum 400-600 $\mu$, mixed with short, sparse brown hairs; those on scutellum and metanotum $600 \mu$; those on mesepisternum $600-800 \mu$; propodeal corbicula long, not well arranged, with internal sparse, simple hairs, brown; trochanteral floccus imperfect, whitish; femoral floccus dense; tibial scopal hairs long, simple, brown, slightly paler along inner margin. Hairs on metasomal terga sparse; those on terga 1-2 long, whitish; those on terga 3-4 short, black; terga 2-4 with short, white hair bands, interrupted on terga 2-3; caudal fimbria brown; sterna 2-5 with whitish subapical fimbriae.

Structure: Head: HL/HW = 0.90. HW: MsW: MtW $=2.6: 2.6: 2.8$. Vertex short, weakly tessellate, shiny with minute PP. OOD: POD: $O C D=0.55: 0.4: 0.2$. FL1 slightly longer than FL2+3, FL2 = FL3 with broader than long, intermediate flagellar segments about quadrate. Eyes with inner margins paralleled. Facial fovea narrow, deep, separated from eye by narrow polished space, extending to below a line at lower margins of antennal fossae, FVL $=0.9 \mathrm{~mm}, \mathrm{FVW}=0.2 \mathrm{~mm}$. Supraclypeal area dulled by close minute PP. Face above antennal fossae with dense longitudinal rugulae and weak interrugal PP, surface shagreening. Facial quadrangle slightly longer than broad (about 2.0: 1.9). Clypeus weakly convex, smooth and shiny medially, weakly tessellate laterally, surface with PPø20 $\mu$, IS $=0.5-1$ or sparser, with median indistinct to distinct longitudinal impunctate line, $\mathrm{CPL}=1.0 \mathrm{~mm}$. Process of labrum subtrapezoidal, entire to weakly emarginate apically, surface smooth and shiny. Labrum apical to process flat, smooth and shiny without crista. Lower paraocular area shagreened by crowded minute PP. Malar space rather short, about one-sixth time as long as width of basal mandible. Genal area broader than eye, GW: EW $=0.7: 0.5$, surface weakly tessellate, shiny with microscopic PP, IS $=2$. Mesosoma: Pronotum reticularly shagreened with weak small PP. Mesoscutum weakly tessellate, surface shiny with fine $\mathrm{PP} \varnothing 20 \mu$, IS $=0.5$ or denser. Scutellum as in mesoscutum. Propodeal enclosure ill defined, densely tessellate, with basal short rugulae; dorsal face of propodeum roughened. Mesepisternum densely tessellate with minute PP, IS $=1-2$. Vein 1 st $m-c u$ meeting second submarginal cell before middle of cell. Metasoma: Metasomal terga weakly tessellate, shiny; surface scattered microscopic PP, IS = 2-3 or sparser, PP distinct on terga 2-3; posterior depressions of terga moderately indicated; pygidial plate $\mathrm{V}$-shaped with weak internal triangular area. Sterna 2-5 finely tessellate and finely punctate, surface with minute PP, IS =1-2 except base narrowly impunctate.

Male: BL $8.0 \mathrm{~mm}$, WL $6.5 \mathrm{~mm}$.

Color: As in female.

Pubescence: Generally as in female except as follows: hairs on clypeus and lower part of genal area whitish; those on mesepisternum dull white mixed with brown; metasomal terga 4-5 with weak apical fasciae; sterna 3-5 with complete short, white subapical fimbriae.

Structure: $\mathrm{HL} / \mathrm{HW}=0.90 . \mathrm{HW}: \mathrm{MsW}: \mathrm{MtW}=2.5$ : 2.3: 2.3. Vertex roughened above lateral ocelli, smooth and shiny near top of eye with sparse minute PP. OOD: POD: $\mathrm{OCD}=0.5:$ 0.4: 0.2. FL1 > FL2, FL1 < FL2+3. Eyes with inner margins subparalleled. Supraclypeal area and face above antennal fossae sculptured as in female. Facial quadrangle slightly longer than broad (about 1.9: 1.8). Clypeus weakly convex medially, surface smooth and shiny with $\mathrm{PP} 20 \mu$, IS =1-2, PP smaller and denser at extreme angle area, with median indistinct impunctate line, apical rim upturned, $\mathrm{CPL}=0.9 \mathrm{~mm}$. Process of labrum small, entire apically. Mandibles decussate. Lower paraocular area as in female, but PP crowded. Malar space as in female. Genal area broadened, GW: $\mathrm{EW}=0.8: 0.5$, surface broadly smooth and shiny near eye with irregular PP, shagreened posteriorly. Mesosoma: 
Pronotum densely reticularly shagreened. Mesoscutum broadly weakly tessellate, shiny with PPø15 $\mu$, IS =0.5-1. Scutellum as in mesoscutum, but PP denser. Propodeum and mesepisternum sculptured as in female. Wing venation as in female. Metasoma: Metasomal terga smooth and shiny, tergum 1 scattered microscopic PP, irregular in distribution; terga 2-3 with microscopic $\mathrm{PP}$, IS = 1-2; terga 4-5 with obscure PP; posterior depressions of terga well indicated. Sterna 2-5 smooth and shiny with weak, rather sparse PP; sternum 6 flat, not emarginate.

Specimens examined: Holotype female and allotype (Institute of Zoology, Academia Sinica, China), Mangkang, 3,800 m, Xizang Autn. Region, China, 22. vi. 1976 (Y-h. Han); Holotype of A. subopercula, Mangkang, 4,500 m, Xizang Autn. Region, China, 16. vi. 1976 (Y-h. Han).

Remarks: This species is similar to A. communisella $\mathrm{n}$. sp. in having the red metasomal terga partly and the emarginated labral process, but the female can be separated from that of communisella by the clypeus weakly tessellate with moderate PP, shinier, the face of head and lateral thorax with brown hairs and the propodeum roughened.

Distribution: China (Xizang Autn. Region).

Floral association: Not available.

\section{Andrena (Euandrena) sichuana n. sp.}

(Fig. 1: A-E)

Female: BL 8.0-9.0 mm, WL 6.7-7.0 mm ( $\mathrm{n}=2)$.

Color: Flagellum reddish brown beneath; mandible with apical half and more reddened; wing membranes moderately brown, veins and pterostigma dark reddish brown; tibial spurs yellow; metasomal terga 1-2 with apical areas reddish, posterior depressions of metasomal terga reddish yellow or moderately so.

Pubescence: Hairs on head not so dense, fulvous to brown; those on clypeus 200-400 $\mu$, sparse, fulvous; those on antennal area fulvous with brown; those on vertex $400-600 \mu$, brown; those on genal area fulvous, outer margins of eyes brown; facial fovea dark brown. Hairs on

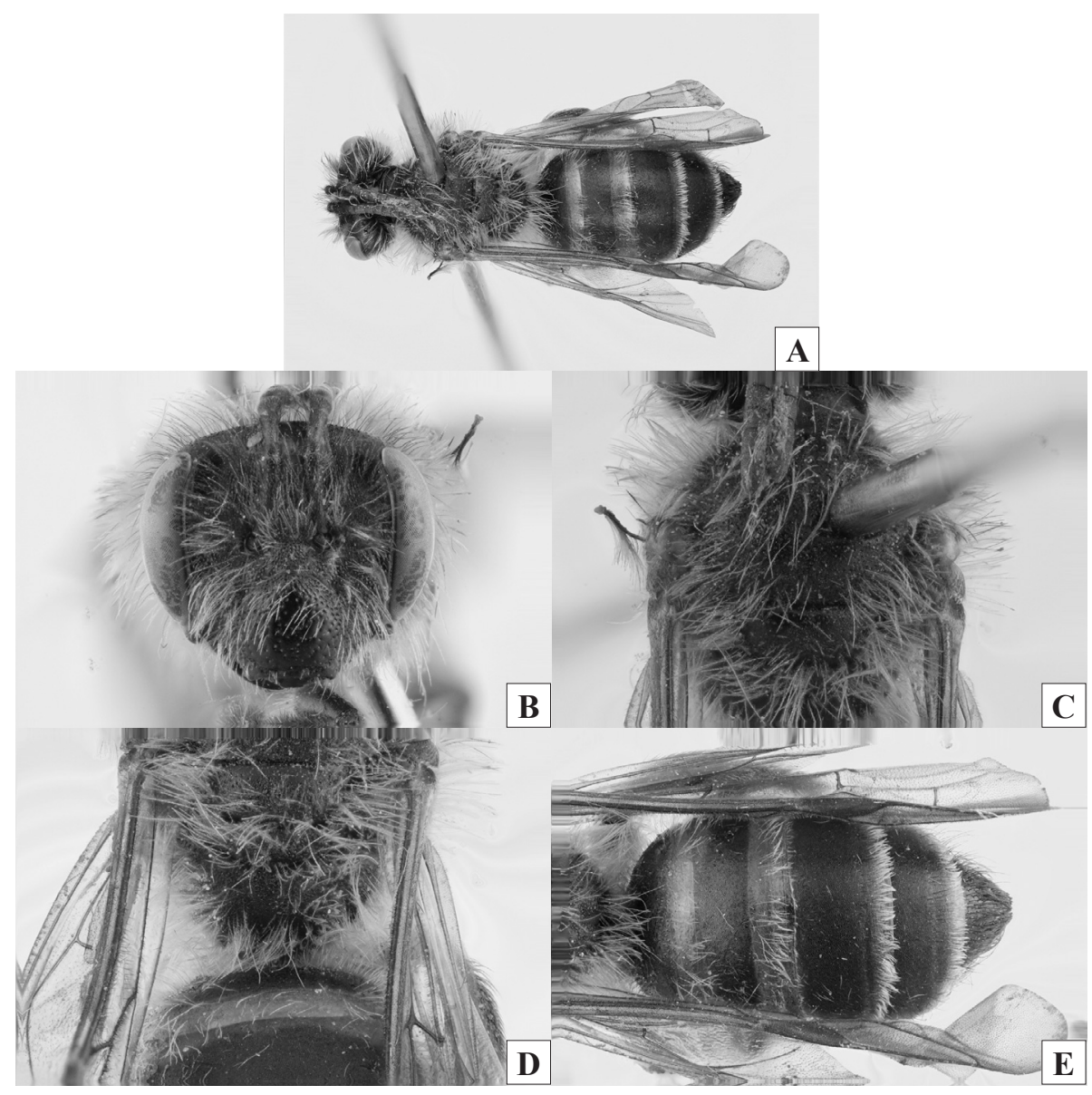

Fig. 1. Andrena (Euandrena) rufosignata n. sp., female. A: general habitus in dorsal view; B: head in frontal view; C: mesoscutum; D: propodeum; E: metasomal terga. 
mesoscutum about $500 \mu$, dense, fulvous; those on scutellum $300-500 \mu$; those on mesepisternum $800 \mu$, yellowish; propodeal corbicula with not well arranged long dorsal fringes, with internal sparse, simple hairs; trochanteral floccus imperfect, yellowish; femoral floccus dense; tibial scopal hairs long, simple, brown. Hairs on metasomal terga 1-2 short, erect, yellowish white; those on terga 3-4 dense, black; terga 2-4 with short, white hair bands; caudal fimbria black; sterna 2-4 with fulvous subapical fimbriae, sternum 5 with brown fimbria.

Structure: Head: $\mathrm{HL} / \mathrm{HW}=0.84$. HW: MsW: $\mathrm{MtW}=$ 2.7: 2.7: 3.0. Vertex short, densely tessellate. OOD: POD: $\mathrm{OCD}=0.5: 0.4: 0.2$. FL1 about as long as FL2+3, FL2 = FL3 broader than long. Eyes with inner margins subparalleled. Facial fovea short, not extending to below a line at lower margins of antennal fossae, separated from eye by a punctated space, $\mathrm{FVL}=1.0 \mathrm{~mm}, \mathrm{FVW}=0.2 \mathrm{~mm}$, narrowing to below. Supraclypeal area dulled by irregular rugulae. Face above antennal fossae with fine longitudinal rugulae and interrugal PP, surface dull. Facial quadrangle as broad as long (about 2.0: 2.0). Clypeus nearly flattened, surface smooth and shiny except lateral sides narrowly tessellate, $\mathrm{PP} 20-40 \mu$, IS $=0.5-2$, irregular in distribution, denser and smaller at lateral angles, $\mathrm{CPL}=$ $0.9 \mathrm{~mm}$. Process of labrum trapezoidal, weakly emarginate apically. Labrum apical to process without cristae. Lower paraocular area dulled by coarse minute PP, smooth and shiny near inner margin of eye. Malar space linear. Genal area as broad as eye, GW: $\mathrm{EW}=0.7$ : 0.7 , surface finely tessellate, PP obscured. Mesosoma: Pronotum finely tessellate. Mesoscutum densely tessellate marginally, weakly tessellate to smooth and shiny medially with $\mathrm{PP} 20 \mu$, IS $<0.5$. Scutellum as in mesoscutum. Propodeal enclosure ill defined, finely granulate, with basal short, weak rugulae; dorsal face of propodeum shagreened by coarse tessellation. Mesepisternum densely tessellate with obscure PP. Vein 1st $m$-cu meeting second submarginal cell before middle of cell. Metasoma: Metasomal terga finely tessellate, tergum 1 with microscopic PP medially; apical area of tergum 1 and terga 2-4 impunctate; posterior depressions of terga not well indicated; pygidial plate $\mathrm{V}$-shaped with raised triangular area. Sterna 2-5 weakly tessellate, shiny; impunctate basally, finely punctate apically with minute $\mathrm{PP}, \mathrm{IS}=1-2$.

Male: BL $8.0 \mathrm{~mm}$, WL $7.0 \mathrm{~mm}(\mathrm{n}=1)$.

Color: Flagellum reddish brown beneath; mandible reddened apically; wing, tibial spurs, metasomal terga as in female.

Pubescence: Hairs on head and thorax dense, yellowish to brown; those on clypeus $400-600 \mu$, pale yellow; those on face along inner margin of eye brown; those on vertex $600-800 \mu$, whitish with brown; those on genal area yellowish white, outer margins of eyes brown; those on mesoscutum about 500-600 $\mu$, fulvous; those on scutellum $300-500 \mu$; those on mesepisternum $800 \mu$, paler, intermixed with a few brown. Hairs on metasomal terga similar to female; terga 2-4 with short, white hair bands; caudal fimbria black; sterna with white hairs; sterna 2-5 with indistinct subapical fimbriae.

Structure: Head: $\mathrm{HL} / \mathrm{HW}=0.86$. HW: $\mathrm{MsW}: \mathrm{MtW}=$ 2.5: 2.4: 2.4. Vertex dulled by coarsely tessellation. OOD: POD: $\mathrm{OCD}=0.55: 0.3: 0.2$ FL1 $=$ FL3 > FL2, FL2 broader than long. Eyes with inner margins paralleled. Supraclypeal area and face above antennal fossae sculptured as in female. Facial quadrangle as broad as long (about 1.9: 1.9). Clypeus similar to female, but PP smaller and denser, $\mathrm{CPL}=0.9 \mathrm{~mm}$. Process of labrum as in female, but smaller. Mandibles long, decussate. Lower paraocular area weakly tessellate, weakly shagreened by crowded PP. Malar space linear. Genal area broader than eye, $\mathrm{GW}: \mathrm{EW}=0.7: 0.55$, surface roughened. Mesosoma: Pronotum finely tessellate, feebly shiny with obscure minute PP. Mesoscutum and scutellum densely tessellate, dulled with obscure minute PP; propodeum and mesepisternum sculptured as in female. Vein 1st $m$-cu meeting second submarginal cell at middle of cell. Metasoma: Metasomal terga finely tessellate, impunctate; posterior depressions of terga well indicated. Sterna 2-5 weakly tessellate, shiny, scattered with weak minute PP; sternum 6 flat, not emarginate.

Type material: Holotype male, Mt. Emeishan, 550-750 m, Sichuan Province, China, 29. iii. 1957 (K-r. Huang); Paratypes: Yunnan Province: 1 female, Kunming City, 27. v. 1974 (D-x. Liao).

Remarks: This species is closely related to Andrena communiella $\mathrm{n}$. sp. The female can be separated from communisella in female by the clypeus sparsely punctate, the first flagellar segment as long as the next two segments together and the mesoscutum and scutellum tessellate.

Distribution: China (Sichuan, Yunnan Provs.).

Floral association: Not available.

\section{Andrena (Euandrena) communisella $\mathrm{n}$. $\mathrm{sp}$.} (Fig. 2: A-E)

Andrena communis (nec Smith): Wu, 1988, Insects Mt. Namjagbarwa Region Xizang, Apoidea, 545 [female, China].

Female: BL 9.0-10.0 mm, WL 8.2-8.5 mm (n=2).

Color: Flagellum brown beneath; mandible with apical 
third reddened; wing membranes subhyaline, moderately brown, veins and pterostigma reddish brown; tibial spurs testaceous; metasomal terga 1 with basal area, tergum 2 and basal area of tergum 3 ferruginous, posterior margins of terga red to reddish brown.

Pubescence: Hairs on head sparse, dull yellow to black; those on clypeus $300-500 \mu$, dull yellow; those on face along inner margins of eyes black; those on vertex 400-500 $\mu$; dull yellow mixed with brown; facial fovea brown. Hairs on thorax dull yellow; those on anterior margin of mesoscutum 140-400 $\mu$, dull yellow, naked medially; those on scutellum $400-600 \mu$; those on mesepisternum $600 \mu$; propodeal corbicula developed, with internal rather sparse, simple hairs; trochanteral floccus imperfect, yellowish; femoral floccus dense; tibial scopal hairs long, simple, yellow. Hairs on metasomal terga short, sparse; those on terga 1-2 yellow; those on terga 3-4 black; terga 2-4 with weak, white hair bands, interrupted on tergum 2; caudal fimbria brown; sterna 2-5 with long, sparse whitish subapical fimbriae.
Structure: Head: HL/HW = 0.83. HW: MsW: MtW = 3.0: 3.0: 3.0. Vertex short, densely tessellate. OOD: POD: $\mathrm{OCD}=0.6: 0.35: 0.15$. FL1 > FL2+3, FL2 = FL3 broader than long, intermediate flagellar segments about quadrate. Eyes with inner margins paralleled. Facial fovea narrow, deep, separated from eye by broad punctate space, extending to below a line at lower margins of antennal fossae, $\mathrm{FVL}=1.0 \mathrm{~mm}, \mathrm{FVW}=0.15 \mathrm{~mm}$. Supraclypeal area dulled by coarse PP. Face above antennal fossae with fine longitudinal rugulae and weak interrugal PP, surface shagreening. Facial quadrangle as broad as long (about 2.1: 2.1). Clypeus well convex, surface densely tessellate basally and laterally, smooth and shiny medioapically, with $\mathrm{PP} 40 \mu$, IS $<0.5$, extreme angle area with smaller РРø20 $\mu$, with median indistinct longitudinal impunctate line, $\mathrm{CPL}=1.1 \mathrm{~mm}$. Process of labrum trapezoidal, deeply emarginate apically, surface smooth and shiny. Labrum apical to process convex, smooth and shiny without crista. Lower paraocular area closely punctate with $\mathrm{PP} 20 \mu, \mathrm{IS}=0.5$, surface weakly shiny. Malar space

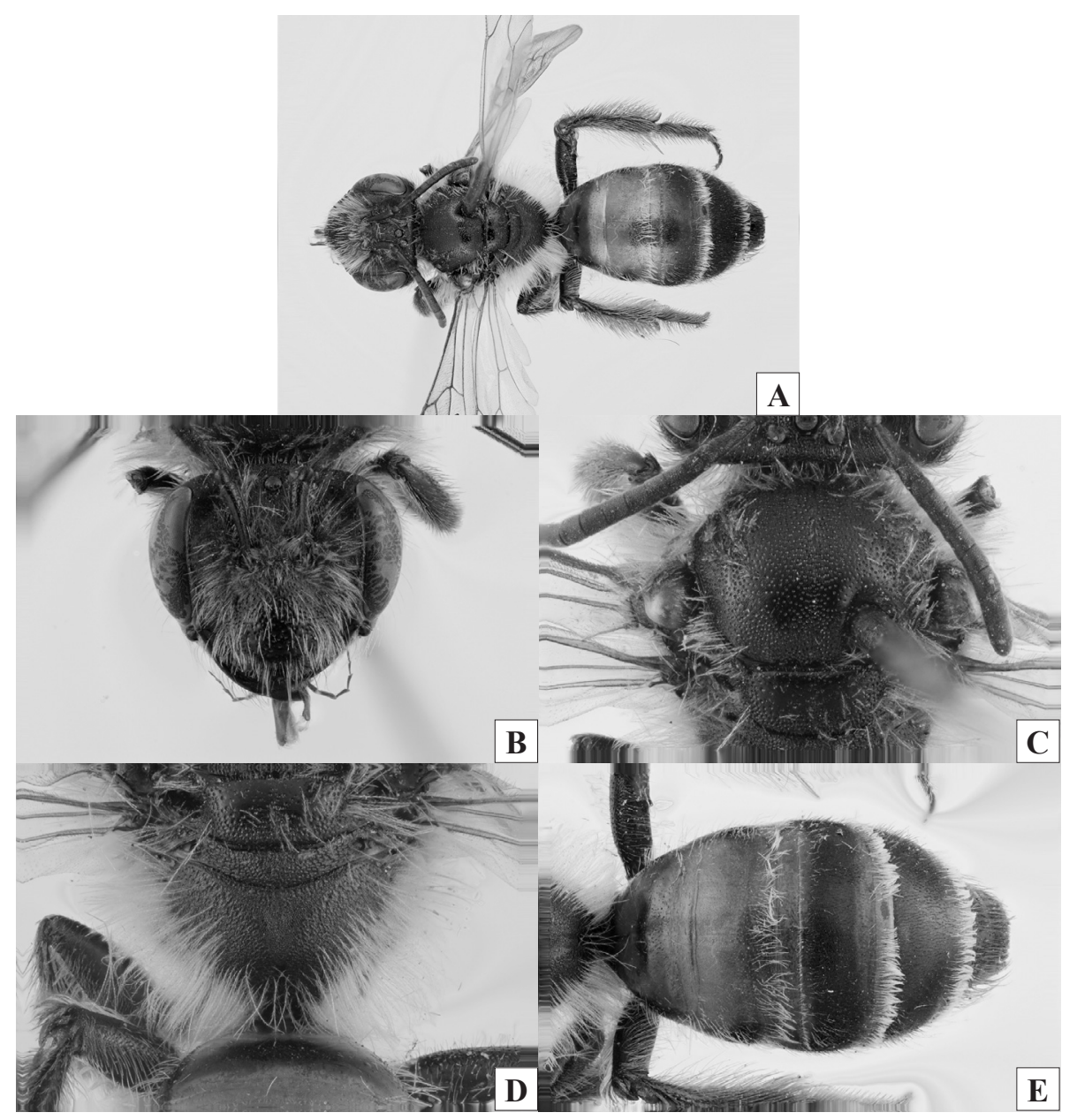

Fig. 2. Andrena (Euandrena) communisilla $\mathbf{n}$. sp., female. A: general habitus in dorsal view; B: head in frontal view; C: mesoscutum; D: propodeum; E: metasomal terga. 
nearly linear. Genal area slightly broader than eye, GW: $\mathrm{EW}=0.8: 0.7$, surface weakly tessellate, shiny with sparse minute PP, IS $=2$ posteriorly, close PP near eye. Mesosoma: Pronotum finely reticularly shagreened. Mesoscutum finely tessellate peripherally, weakly tessellate medially with rounded PРø15 $\mu$, IS $=0.5-2$. Scutellum smooth and shiny medially with PP irregular in distribution. Propodeal enclosure finely granulate, rather weakly rugulose at basal margin; dorsal face of propodeum coarsely tessellate, surface roughened. Mesepisternum sculptured as in dorsal surface of propodeum. Vein 1st $m$-cu meeting second submarginal cell near middle of cell. Metasoma: Metasomal tergum 1 smooth with microscopic PP apically, tergum 2 with minute PP, IS = 1-3 basally; terga 3-4 with obscure minute PP; posterior depressions of terga not well indicated; pygidial plate $\mathrm{V}$-shaped with weak internal triangular area. Sterna 2-5 finely tessellate with rather sparse minute PP apically.

Male: Unknown.

Type material: Holotype female, Gedang, 2,000 m, Metuo County, Xizang Autn. Region, China, 8. x. 1982 (Y-h. Han); Paratype: Sichuan Province: 1 female, Emeishan, 550-750 m, 19. v. 1957 (z-y. Wang).

Remarks: This species is very close to the preceding species except the larger size, the clypeus more coarsely punctate, the mandibles decussate, the shinier mesoscutum and scutellum. Wu (1988) recorded this species as communis Smith of India, but communis has crowded punctures on the metasomal terga and maybe belongs to the subgenus Oreomelissa (Gusenleitner and Schwarz, 2002).

Distribution: China (Xizang Autn. Region, Sichuan Prov.).

Floral association: Not available.

\section{Andrena (Euandrena) tomuerna n. sp.}

Female: BL 7.5-8.5 mm, WL 6.5-7.0 mm (n=3).

Color: Flagellum reddish brown to brown beneath; mandible with apical third or more reddened; wing membranes subhyaline, veins and pterostigma reddish brown; tibial spurs testaceous; posterior margins of metasomal terga yellow to reddish brown subhyaline.

Pubescence: Hairs on head sparse, pale yellow to whitish; those on clypeus 200-300 $\mu$, those on vertex 400$600 \mu$; those on genal area moderately dense; facial fovea brown. Hairs on mesoscutum short $200-400 \mu$, pale yellow; those on scutellum $200 \mu$ anteriorly, yellow, those on posterior margin of scutellum and metanotum long and dense, yellow; those on mesepisternum sparse, paler; propodeal corbicula poorly developed, dorsal fringes not curling, with internal sparse, simple hairs; trochanteral floccus imperfect, whitish; femoral floccus dense; tibial scopal hairs long, simple, yellow. Hairs on metasomal terga short, sparse, whitish; terga 2-4 with short, weak, interrupted apical fasciae, white; caudal fimbria yellowish white; sterna 2-5 with incomplete, whitish subapical fimbriae.

Structure: Head: $\mathrm{HL} / \mathrm{HW}=0.83$. HW: $\mathrm{MsW}: \mathrm{MtW}=$ 2.6: 2.6: 2.8. Vertex short, shagreened. OOD: POD: OCD $=0.5: 0.35: 0.1 . \mathrm{FL} 1=\mathrm{FL} 2+3, \mathrm{FL} 2=\mathrm{FL} 3$ broader than long, intermediate flagellar segments about quadrate. Eyes with inner margins paralleled. Facial fovea narrow, exceeding below a line at lower margins of antennal fossae, $\mathrm{FVL}=1.0 \mathrm{~mm}$, FVW $=0.2 \mathrm{~mm}$. Supraclypeal area densely tessellate with obscure minute PP. Face above antennal fossae with fine longitudinal rugulae and weak interrugal PP. Facial quadrangle as broad as long (about 1.8: 1.8). Clypeus strongly convex, apical margin concave, surface smooth and shiny except basal $1 / 4$, apical 3/4 with crowded $\mathrm{PP} \varnothing 20-30 \mu$, IS $<0.5$, with median narrow impunctate ridge, $\mathrm{CPL}=0.9 \mathrm{~mm}$. Process of labrum small, trapezoidal, entire apically, surface smooth and shiny. Labrum apical to process with weak transverse sulcus, with median two cristae, composed of small concave area. Lower paraocular area crowdedly punctate with small PP. Malar space linear. Genal area as broad as eye, GW: EW = 0.6: 0.6, surface densely tessellate except near eye, PP obscured. Mesosoma: Pronotum densely tessellate with dense minute PP. Mesoscutum and scutellum densely tessellate with minute PP, IS $<1$, but denser medially. Propodeal enclosure densely tessellate, irregularly shagreened; dorsal face of propodeum coarsely shagreened. Mesepisternum finely shagreened with obscure PP. Vein 1st $m-c u$ meeting second submarginal cell at middle of cell. Metasoma: Metasomal terga finely tessellate, feebly shiny, surface impunctate or PP obscured; posterior depressions of terga well indicated; pygidial plate V-shaped with weak raised triangular area. Sterna 2-5 each densely tessellate, surface with fine minute PP except basal margins.

Male: Unknown.

Type material: Holotype female, Mt. Tumorfeng, 2,400 m, Xinjiang Uygur Autn. Region, China, 3. vii. 1977 (Y-h. Han). Paratypes: Same locality and collector as the holotype, 1 female, 26. vi. 1977, 1 female, 6. vii. 1977.

Remarks: This species is similar to European Andrena symphyti Schmiedeknecht in having the coarsely punctate clypeus with raised median impunctate space, but it can 
be separated from the latter by the less roughened and shinier clypeus, the smaller labral process and the densely and minutely punctate mesoscutum.

Distribution: China (Xinjiang Uygur Autn. Region).

Floral association: Not available.

\section{Andrena (Euandrena) tateyamana Tamasawa et Hirashima}

Andrena (Euandrena) tateyamana Tamasawa et Hirashima, 1984, Esakia, (22), 103-105 [female \& male, Japan]; Tadauchi and Hirashima, 1984, Esakia, (22): 108, 109 [female \& male, in key].

Specimens Examined: Holotype female (Type no. 2468, Kyushu Univ.) and several paratypes, Mt. Tateyama, Toyama Pref., Japan, 12. viii, 1981 (S. Tamasawa). Other material: China: Heilongjiang Province: 1 female, Wutalenchieh (now is Wudalianchi), 12. vii. 1937 (A. S. Loukashkin). Jilin Province: 7 females, Baihe, Changbaishan, 750 m, 2-4. vii. 1987 (J-g. Fan).
Distribution: China (new record, Heilongjiang, Jilin Provs.); Japan (central Honshu).

Floral association: Not available.

\section{Andrena (Euandrena) carbointegra n. sp.}

(Fig. 3: A-E)

Female: BL 9.0-11 mm, WL 8.2-9.5 mm (n=3).

Color: Flagellum brown beneath; mandible with apical third reddened; wing membranes subhyaline, veins and pterostigma reddish brown; tibial spurs yellow; posterior depressions of metasomal terga dark reddish brown.

Pubescence: Hairs on head moderately sparse, black except vertex mixed with whitish; those on clypeus scanty; those on antennal area long; those on vertex 600$800 \mu$; facial fovea brown. Hairs on mesoscutum 400$600 \mu$, sparse, black mixed with pale anteriorly; those on scutellum and metanotum black with pale; those on mesepisternum dense, dark brown; propodeal corbicula long with not well arranged dorsal fringes, with internal short, sparse simple hairs, brown; trochanteral floccus

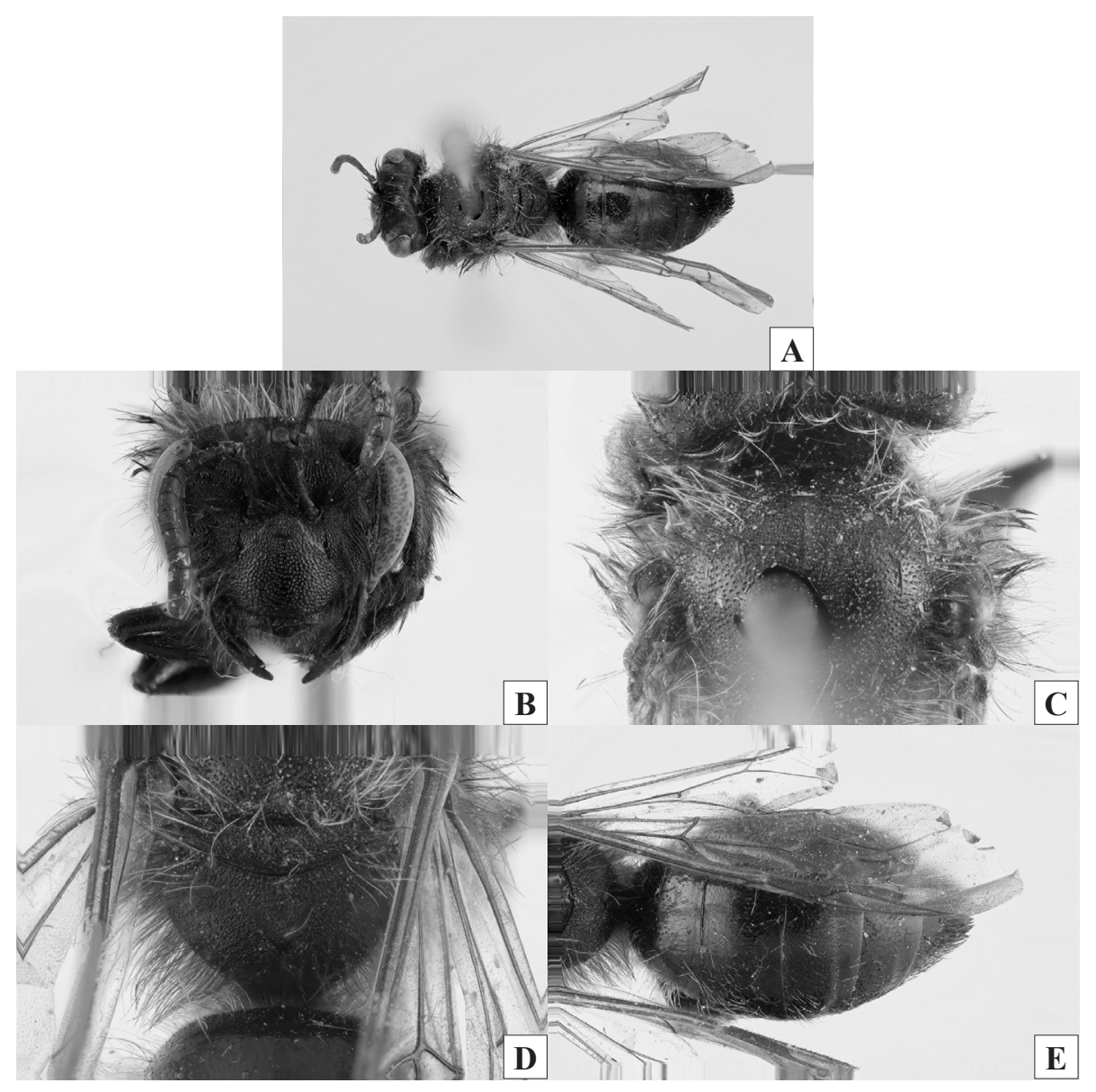

Fig. 3. Andrena (Euandrena) carbointegralla n. sp, female. A: general habitus in dorsal view; B: head in frontal view; C: mesoscutum; D: propodeum; E: metasomal terga. 
imperfect, sparse and short at basal half, brown; femoral floccus dense, whitish; tibial scopal hairs long, simple, brown, inner margin whitish. Hairs on metasomal terga rather sparse; tergum 1 with long pale hairs, terga 2-4 with short, black hairs, without apical fasciae; caudal fimbria brown; sterna 2-5 with incomplete brown subapical fimbriae.

Structure: Head: $\mathrm{HL} / \mathrm{HW}=0.80 . \mathrm{HW}: \mathrm{MsW}: \mathrm{MtW}=$ 3.2: 3.2: 3.5. Vertex short, densely tessellate. OOD: POD: $\mathrm{OCD}=0.7: 0.4: 0.16$. FL1 $>$ FL2+3, FL2 = FL3, broader than long, intermediate flagellar segments broader than long. Eyes with inner margins subparalleled. Facial fovea narrow, extending to below a line at lower margins of antennal fossae, separated from eye by narrow punctate space, $F V L=1.1 \mathrm{~mm}, \mathrm{FVW}=0.3 \mathrm{~mm}$. Supraclypeal area tessellate with fine minute PP. Face above antennal fossae with fine longitudinal rugulae and weak interrugal PP, surface shagreening. Facial quadrangle broader than long (about 2.4: 2.2). Clypeus nearly flattened medially, weakly tessellate, rugulo-punctate with $Р Р ø 30 \mu$, IS $<0.5$, shiny, $\mathrm{CPL}=1.1 \mathrm{~mm}$. Process of labrum large, trapezoidal, entire apically. Labrum apical to process without cristae. Lower paraocular area as in clypeus, but PP smaller. Malar space rather short, about one-sixth time as long as width of basal mandible. Genal area broader than eye, $\mathrm{GW}: \mathrm{EW}=0.9: 0.7$, surface finely tessellate posteriorly with sparse minute PP, smooth and shiny near eye. Mesosoma: Pronotum finely tessellate. Mesoscutum densely tessellate anteriorly and posteriorly, finely tessellate medially with minute PP, IS $=1$. Scutellum as in mesoscutum, but PP denser. Propodeal enclosure rugulose basally, granulate apically; dorsal face of propodeum densely tessellate with weak PP, shagreened. Mesepisternum densely tessellate with weak PP. Vein 1st $m-c u$ meeting second submarginal cell at middle of cell. Metasoma: Metasomal terga weakly tessellate, tergum 1 with minute PP, IS $=1-2$ at basal areas, impunctate at apical areas; tergum 4 with sparser and weaker PP; posterior depressions of terga well indicated; pygidial plate V-shaped. Sterna 2-5 weakly tessellate with distinct close minute PP.

Male: Unknown.

Type material: Holotype female, north slope of Mt. Tianshan, 1,600 m, Wu-Ku Road, Xinjiang Uygur Autn. Region, China, 11. vi. 1960 (S-y. Wang); Paratypes: 2 females, same locality and collector as the holotype, 5 . vi. 1960.

Remarks: This new species is similar to Andrena bicolor Fabricius in having the black hairs on head and the weakly punctated metasomal terga. The female can be separated from that of bicolor by the larger size, the black hairs on thorax, the sparser and weaker PP on mesoscutum and the metasomal terga with scanty hairs. It is also similar to A. tateyamana Tamasawa et Hirashima, but can be separated from the latter by the clypeus densely punctate, the black hairs on head and thorax and the propodeal enclosure less rugulose.

Distribution: China (Xinjiang Uygur Autn. Region).

Floral association: Not available.

\section{Andrena (Euandrena) bicolor Fabricius}

Andrena bicolor Fabricius. 1775, Syst. Ent., 376 [female, Denmark].

Melitta gwynana Kirby, 1802, Monogr. Apum. Angl., 2: 120 [female \& male, England].

Andrena gwynana: Schmiedeknecht, 1883, Apid. Europ., 1: 588-591; Stöckhert, 1930, Hym. Nord-und Mitteleurop., 916.918 [female \& male, in key].

Andrena (Euandrena) bicolor: Hedicke, 1933, Mitt. Zool. Mus. Berlin, 19: 213; Osytshnjuk, 1977, Faun. Ukraini, 12(5): 219-221.Gusenleitner and Schwarz, 2002, Entomofauna, 12(suppl.): 123-126.

Specimens examined: China: Xinjiang Uygur Autn. Region: 1 female, Azhubai, 1750 m, Aletai, 5. viii. 1960 (S-y. Wang). Mongolia: Central aimak: 2 females, UlanBaator, 1,500-1,800 m, 22-23. vii. 1965 and 4. vi. 1966 (Z. Ksazab).

Distribution: China (new record, Xinjiang Uygur Autn. Region); Mongolia (new record, central Aimak); Europe.

Floral association: Not available.

\section{Andrena (Euandrena) hoffmanni Strand}

Andrena hoffmanni Strand, 1915, Ent. Mitt., 4: 69-70 [male, China]; Yasumatsu, 1941, Peking nat. Hist. Bull., 15: 276 [in list].

Andrena (Euandrena) hoffmanni: Xu and Tadauchi, 1998, Esakia, (38): 91-92 [redescription]; Gusenleitner and Schwarz, 2002, Entomofauna, 12(suppl.): 348.

Female (new to science): BL 8.5-9.5 mm, WL 7.5-7.7 $\mathrm{mm}(\mathrm{n}=10)$.

Color: Flagellum brown beneath; mandible with apical half or more reddened; wing membranes hyaline, veins and pterostigma yellowish brown; tibial spurs yellowish; posterior depressions of metasomal terga dark reddish brown.

Pubescence: Hairs on head sparse, dull yellow; those 
on clypeus $400-500 \mu$; those on vertex $500-600 \mu$; facial fovea brown above, whitish below. Hairs on mesoscutum and scutellum $300-600 \mu$, dense, dull yellow; those on mesepisternum $700 \mu$, yellowish; propodeal corbicula not well developed, dorsal fringes sparse, with internal sparse, simple hairs; trochanteral floccus imperfect, sparse, whitish; femoral floccus dense; tibial scopal hairs long, simple, white. Hairs on metasomal terga short, sparse, white; terga 2-4 with short, weak interrupted apical fasciae, white; caudal fimbria light brown intermixed with dull white; sterna 2-5 with weak, whitish subapical fimbriae.

Structure: Head: $\mathrm{HL} / \mathrm{HW}=0.84$. HW: $\mathrm{MsW}: \mathrm{MtW}=$ 2.6: 2.6: 3.0. Vertex short, finely tessellate. OOD: POD: $\mathrm{OCD}=0.55: 0.3: 0.15 . \mathrm{FL} 1=\mathrm{FL} 2+3, \mathrm{FL} 2=\mathrm{FL} 3$ broader than long, intermediate flagellar segments about quadrate. Eyes with inner margins paralleled. Facial fovea narrow, separated from eye by narrow space, extending to below a line at lower margins of antennal fossae, $\mathrm{FVL}=1.0 \mathrm{~mm}$, $\mathrm{FVW}=0.2 \mathrm{~mm}$. Supraclypeal area dulled with weak rugulae. Face above antennal fossae with fine longitudinal rugulae and weak interrugal PP. Facial quadrangle broader than long (about 2.0: 1.8). Clypeus well convex, surface finely tessellate or moderately so, weakly shiny medially, surface scattered with weak shallow minute PP, IS $=1-2$, with median indistinct longitudinal impunctate line, $\mathrm{CPL}=0.9 \mathrm{~mm}$. Process of labrum rectangular, weakly emarginate apically, surface with weak rugulae at base. Labrum apical to process flat, smooth and shiny with weak cristae. Lower paraocular area dulled by coarse punctation. Malar space linear. Genal area slightly broader than eye, $\mathrm{GW}: \mathrm{EW}=0.7: 0.6$, surface densely tessellate, PP obscured. Mesosoma: Pronotum finely tessellate, PP obscured. Mesoscutum and scutellum strongly tessellate, opaque. Propodeal enclosure narrow, ill defined, densely tessellate with weak rugulae at base; dorsal face of propodeum densely tessellate and weakly punctate, surface shagreened. Mesepisternum strongly tessellate. Vein 1st $m$-cu meeting second submarginal cell at middle of cell. Metasoma: Metasomal terga weakly tessellate, shiny, impunctate; posterior depressions of terga narrow, well indicated; pygidial plate $\mathrm{V}$-shaped with rounded apex, with internal weak triangular area. Sterna 2-5 weakly tessellate, impunctate at basal halves, finely punctate with minute PP, IS $=1-1.5$ at apical halves.

Specimens examined: Holotype male (DEI, Eberswalde, Germany), Tsingtau, Prof. Hoffmann, April. Other material: China: Shanghai (A. Savio): 1 female, 20. iii. 1933; 1 female, 27. iii. 1933; 1 female, 6. iv. 1933; 2 females, 7. iv. 1933; 2 females, 11. iv. 1933; 1 female, 11. iv. 1934. Shanghai (O. Piel): 1 female, 5. iv. 1933; 2 males, 30. iii. 1930; 1 female, 31. iii. 1931; 1 male, 29. iii. 1932; 1 male, 20. iv. 1932. Anhui Province: Hefei City, iv. 1956.

Remarks: This species is easily recognized by the process of labrum rectangular.

Distribution: China (Shanghai, Anhui Prov.).

Floral association: Not available.

\section{Andrena (Euandrena) hebes Peréz}

Andrena hebes Peréz, 1905, Bull. Mus. d'Hist. Nat., 1905: 35 [female, Japan]; Cockerell, 1913, Ann. Mag. nat. Hist., (8)11: 154; Alfken, 1932, Mitt. Deut. ent. Ges., 3: 117 [female \& male]; Uéda, 1954, Trans. Shikoku ent. Soc., 4: 50.

Andrena praecociformis Cockerell, 1911, Proc. U. S. nat. Mus., 40: 243[Japan].

Andrena (Euandrena) hebes: Hirashima, 1964, J. Fac. Agr., Kyushu Univ., 13: 46-49; Hirashima, 1966, J. Fac. Agr., Kyushu Univ., 14: 109, 119 [female \& male, in key]; Gusenleitner and Schwarz, 2002, Entomofauna, 12(suppl.): 336.

Specimens examined: A series of specimens preserved in Kyushu University are examined.

Distribution: Japan (Honshu, Sado Is., Shikoku, Kyushu).

Floral association: Japan: Calendula arvensis, Prunus americana ausu, Prunus mume.

\section{Andrena (Euandrena) luridiloma Strand}

Andrena luridiloma Strand, 1915, Ent. Mitt., 4: 72-73 [female, China]; Yasumatsu, 1941, Peking nat. Hist. Bull., 15: 277 [in list].

Andrena (Euandrena) luridiloma: Xu and Tadauchi, 1998, Esakia, (38): 93-94 [redescription] ; Gusenleitner and Schwarz, 2002, Entomofauna, 12(suppl.): 445.

Andrena (Euandrena) stellaria Hirashima, 1964, J. Fac. Agr., Kyushu Univ., 13: 49-51 [female \& male, Japan]; Tadauchi and Hirashima, 1984, Esakia, (22): 108, 109 [female \& male, in key]; Tadauchi and Lee, 1992, Esakia, (32): 49 [in list, Korea].

Specimens examined: Holotype female (DEI, Eberswalde, Germany), Tsingtau, Prof. Hoffmann, Mai. Other material: China: Shanghai (O. Piel): 4 females, 2-20. iv. 1925; 3 females and 1 male, 30. iii. - 6. iv. 1930; 1 female, 16. iv. 1931; 2 males, 31. iii.- 20. iv. 1932; 4 females, 29-31. iii. 1932; 2 females, 15 . iv. 1935; 1 female, 
24. iv. 1996 (O. Tadauchi); 1 female, 26. iv. 1996 (H-1. $\mathrm{Xu})$. Jiangsu Province: 1 female, Zhenjiang, 1. iv. 1919 (O. Piel). Zhejiang Province: 3 females (O. Tadauchi); 2 females (H-1. Xu), Tianmushan, 20-21. iv. 1996. Liaoning Province: 1 female, Dalian, 30. iv. 1940 (S. Asahina). Henan Province: 2 females, 13. iv. 1975 (P-y. Yu). Beijing: 1 female, 22. iv. 1927; 1 female, 14. iv. 1973 (Y-r. Wu).

Distribution: China (Zhejiang, Jiangsu, Shandong, Liaoning, Henan Provs., Shanghai, Beijing); Japan (Hokkaido, Honshu, Sado Is., Shikoku, Kyushu, Tsushima Is., Tanegashima Is.); Korea.

Floral association: China: Brassica campestris, Raphanus sp., Taraxacum sp.

\section{Andrena (Euandrena) yamagishii $\mathrm{n} . \mathrm{sp}$.} (Fig. 4: A-E)

Female: BL 8.5-10.0 mm, WL 7.0-8.0 mm ( $\mathrm{n}=13)$.

Color: Flagellum brown beneath; mandible with apical half or less reddened; wing membranes subhyaline, weakly brown, veins reddish brown, pterostigma black; tibial spurs testaceous; posterior depressions of metasomal terga dark reddish brown.

Pubescence: Hairs on head sparse; those on clypeus $200-400 \mu$, dull yellow to bright brown; those on vertex 400-600 $\mu$, dull yellow; those on genal area short, dense, dull yellow; facial fovea brown. Hairs on thorax dense; those on mesoscutum 300-500 $\mu$, yellowish; those on scutellum about $600 \mu$, yellow; those on mesepisternum 500$700 \mu$, paler; propodeal corbicula with not well arranged long dorsal fringes, with internal sparse, simple hairs; trochanteral floccus imperfect, whitish; femoral floccus loose; tibial scopal hairs long, simple, bright yellow. Hairs on metasomal terga short, sparse, white; terga 2-4 with weak apical hair bands, interrupted on terga 2-3; caudal fimbria yellowish brown; sterna 2-5 with long, well-formed whitish subapical fimbriae.

Structure: Head: HL/HW = 0.85. HW: MsW: MtW = 2.7: 2.7: 3.0. Vertex short, densely tessellate. OOD: POD: $\mathrm{OCD}=0.5: 0.35: 0.1 . \mathrm{FL} 1<\mathrm{FL} 2+3$, FL2 = FL3 broader than long. Eyes with inner margins subparalleled. Facial fovea extending to below a line at lower margins of

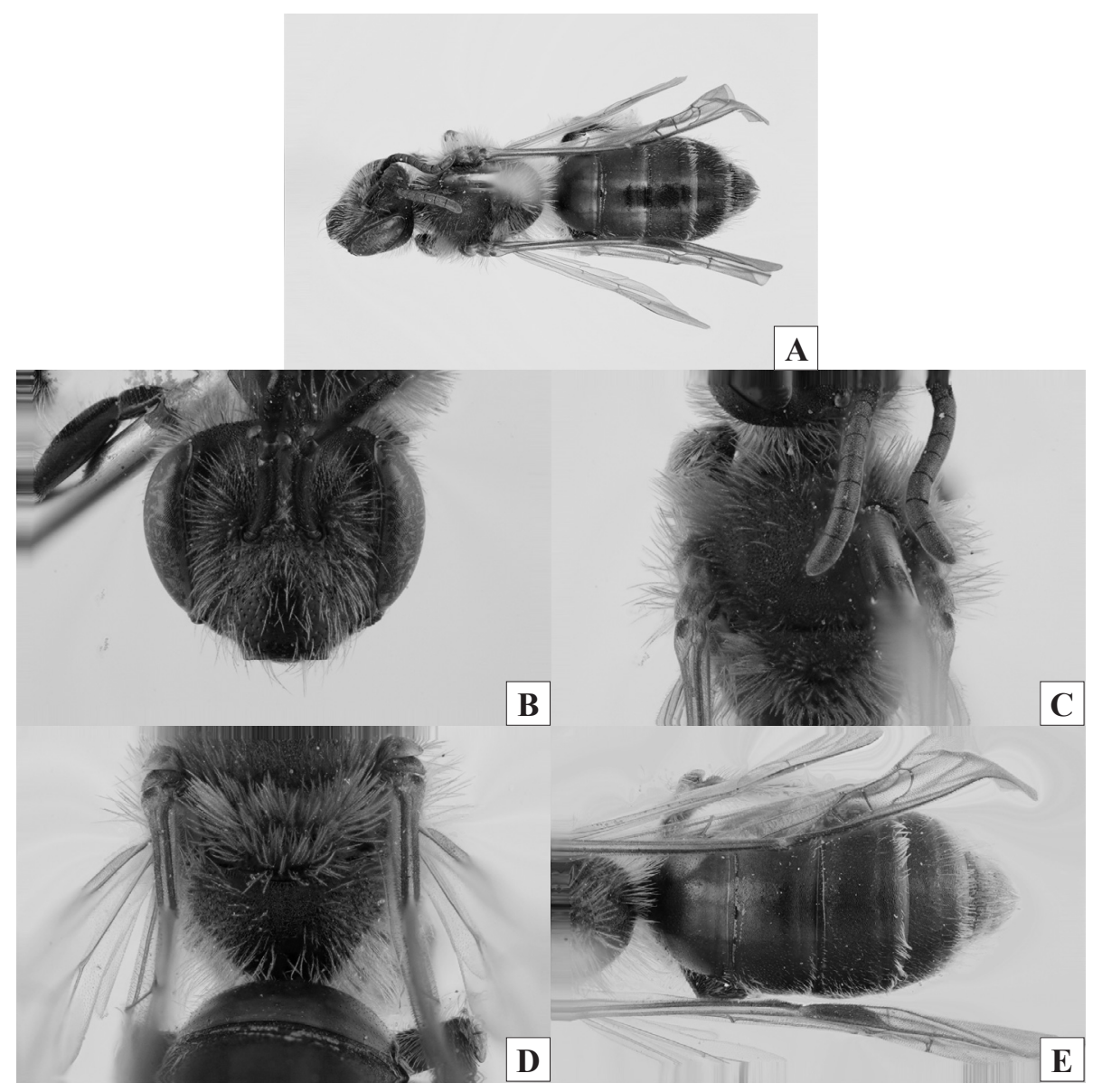

Fig. 4. Andrena (Euandrena) yamagishii n. sp., female. A: general habitus in dorsal view; B: head in frontal view; C: mesoscutum; D: propodeum; E: metasomal terga. 
antennal fossae, separated from eye by narrow punctate space, $F V L=1.0 \mathrm{~mm}, \mathrm{FVW}=0.2 \mathrm{~mm}$. Supraclypeal area and face above antennal fossae sculptured as in hoffmanni. Facial quadrangle as broad as long (about 2.0: 2.0). Clypeus nearly flattened, surface finely tessellate basally and laterally, weakly tessellate or smooth and shiny apicomedially, scattered $\mathrm{PP} 20-30 \mu$, IS $=0.5-2$, median impunctate line narrow or indistinct, $\mathrm{CPL}=0.9 \mathrm{~mm}$. Process of labrum broad, short, trapezoidal, entire apically. Labrum apical to process with a weak transverse sulcus, surface shiny, without cristae. Lower paraocular area finely tessellate with sparse minute PP. Malar space rather short, nearly linear. Genal area as broad as eye, $\mathrm{GW}: \mathrm{EW}=0.6: 0.6$, surface coarsely tessellate. Mesosoma: Pronotum densely tessellate, median longitudinal line obscure. Mesoscutum strongly tessellate, surface with distinct rounded minute PP, IS = 0.5-1 medially. Scutellum densely tessellate, but PP sparser and weak. Propodeal enclosure narrow, well defined, surface finely granulate, occasionally weakly rugulose basally; dorsal face of propodeum coarsely tessellate. Mesepisternum strongly tessellate, surface shagreened. Vein 1 st $m$ - $c u$ meeting second submarginal cell at middle of cell. Metasoma: Metasomal terga finely tessellate, surface weakly shiny, impunctate; posterior depressions of terga not well indicated; pygidial plate large, V-shaped with rounded or truncated apex, with internal distinct raised triangular area. Sterna 2-5 finely tessellate, impunctate basally, finely punctate apically with minute $\mathrm{PP}$, IS $=1$.

Male: Unknown.

Type material: Holotype female, Mt. Tianmushan, Zhejiang Province, China, 18. iv. 1996 (O. Tadauchi); Paratypes: Zhejiang Province: same locality as the holotype: 10 females, 17-21. iv. 1996 (K. Yamagishi); 1 female, 20. iv. 1996 (H-l. Xu); 1 female, Mt. Mokanshan, 6. v. 1936 (O. Piel).

Remarks: This species is similar to Andrena hoffmanni Strand, but can be separated from hoffmanni in female by the broad and short labral process, the coarsely punctated mesoscutum and the more distinct apical hair bands of metasomal terga.

Distribution: China (Zhejiang Prov.)

Floral association: Brassica campestris.

\section{Andrena (Euandrena) subshawella Strand}

Andrena subshawella Strand, 1915, Ent. Mitt., 4: 74-75

[female \& male, China]; Yasumatsu, 1941: Peking nat.

Hist. Bull., 15: 281 [in list].

Andrena (Euandrena) subshawella: $\mathrm{Xu}$ and Tadauchi,
1998, Esakia, (38): $94-97$ [redescription]; Gusenleitner and Schwarz, 2002, Entomofauna, 12(suppl.): 733-734.

Specimens examined: Syntypes of 3 females and 1 male (DEI, Eberswalde, Germany), Tsingtau, Prof. Hoffmann, Juli. Other material: China: Shandong Province: 1 female, Muping, 8. vi. 1958 (J-1. Mao). Heilongjiang Province: Daxinganling: 1 female and 1 male, 18. vii. 1970, 1 male, 23. vii. 1970.

Distribution: China (Shandong, Heilongjiang Provs.).

Floral association: Not available.

\section{Andrena (Euandrena) ruficrus rabicrus Hirashima}

Andrena (Euandrena) ruficrus rabicrus Hirashima, 1957, Mushi, 30: 50 [female, Japan]; Hirashima, 1964, J. Fac. Agr., Kyushu Univ., 13: 51; Hirashima et al., 1979, Esakia, (14): 139 [male, Japan]; Tadauchi and Hirashima, 1984, Esakia, (22): 108, 112; Tadauchi and Lee, 1992, Esakia, (32): 49-50 [Korea].

Specimens examined: Holotype female (Kyushu Univ.), Namari, Yuguchimura, Rikuchu, Honshu, Japan, 15. iv. 1951 (M. Nakaya). Other material: China: Heilongjiang Province: 4 females, Jingpo Lake, Mudanjiang, 23-25. v. 1993 (O. Tadauchi). Jilin Province: 9 females, Baihe, Changbaishan, 30. v.-1. vi. 1993 (O. Tadauchi).

Distribution: China (new record, Heilongjiang, Jilin Provs.); Japan (Hokkaido, Honshu); Korea.

Floral association: China: Taraxacum sp.

\section{Andrena (Euandrena) subruficrus n. sp.}

(Fig. 5: A-E)

Andrena rufohispida: Wu (nec Dours), 1985, Living Things Tianshan Tomurfeng Region Xinjiang, Apoidea, 139 [female, in list].

Female: BL 8.2-9.5 mm, WL 6.5-7.2 mm (n= 8).

Color: Flagellum brown beneath; mandible reddened apically; wing membranes subhyaline, veins and pterostigma yellowish brown; hind tibiae and basitarsi reddish, tibial spurs yellow; posterior depressions of metasomal terga dark reddish brown subhyaline.

Pubescence: Hairs on head sparse, whitish to brown; those on clypeus scanty; those on antennal area and lower paraocular area whitish; those on face along inner margins of eyes brown; those on vertex 500-600 $\mu$, dull white with 
brown ones in sides; facial fovea brown. Hairs on thorax dense, whitish to dull white; those on mesoscutum 400$600 \mu$, not so dense, dull white; those on scutellum 400$600 \mu$; those on mesepisternum $700-800 \mu$, whitish; propodeal corbicula developed with long dorsal fringes, with internal sparse, simple hairs; trochanteral floccus nearly perfect, whitish; femoral floccus dense; tibial scopal hairs long, simple, white. Hairs on metasomal terga short, sparse, whitish, except tergum 1 with long pale hairs at apical area, terga 2-4 without apical fasciae; caudal fimbria light brown intermixed with white; sterna 2-5 with erect, incomplete whitish subapical fimbriae.

Structure: Head: $\mathrm{HL} / \mathrm{HW}=0.76$. HW: MsW: $\mathrm{MtW}=$ 2.7: 2.7: 2.7. Vertex short, densely tessellate. OOD: POD: $\mathrm{OCD}=0.5: 0.3: 0.2 . \mathrm{FL} 1=$ FL2 $+3, \mathrm{FL} 2=$ FL3 broader than long, intermediate flagellar segments about as long as broad. Eyes with inner margins paralleled. Facial fovea short, not extending to below a line at lower margins of antennal fossae, $\mathrm{FVL}=0.9 \mathrm{~mm}, \mathrm{FVW}=0.3 \mathrm{~mm}$. Supraclypeal area dulled. Face above antennal fossae with fine longitudinal rugulae and weak interrugal PP, surface shagreening. Facial quadrangle broader than long (about 2.0: 1.8). Clypeus weakly convex, surface weakly tessellate, shiny with weak PPø15 $\mu$, IS $=0.5-1$, sparser medially, $\mathrm{CPL}=0.9 \mathrm{~mm}$. Process of labrum trapezoidal, entire or weakly emarginate apically. Labrum apical to process without cristae. Lower paraocular area smooth and shiny with same PP as in clypeus. Malar space linear. Genal area as broad as eye, GW: $\mathrm{EW}=0.7$ : 0.7 , surface densely tessellate, PP obscured. Mesosoma: Pronotum weakly tessellate, surface shiny with obscure PP. Mesoscutum densely tessellate without distinct PP. Scutellum finely tessellate, feebly shiny with weak minute PP. Propodeal enclosure ill defined, densely tessellate; dorsal face of propodeum densely tessellate with weak, sparse PP. Mesepisternum densely tessellate with weak minute PP, IS = 1-2 anteriorly, obscured medially. Vein 1 st $m$-cu meeting second submarginal cell at middle of cell. Metasoma: Metasomal terga weakly tessellate, shiny. Tergum 1 scattered with weak PP near apical area; terga 2-4 nearly impunctate; posterior depressions of terga narrow, well indicated; pygidial plate $\mathrm{V}$-shaped with

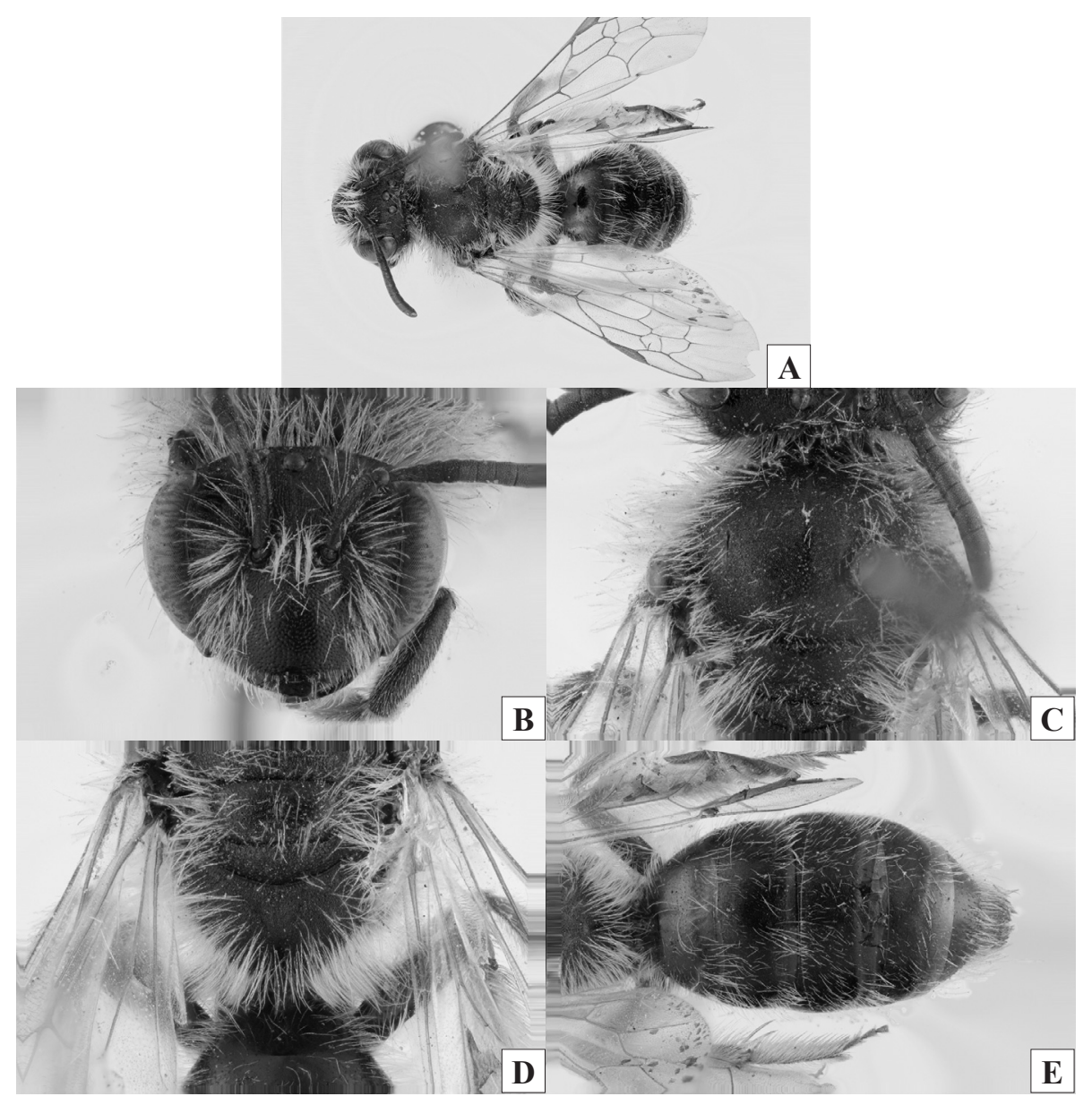

Fig. 5. Andrena (Euandrena) subruficrus n. sp., female. A: general habitus in dorsal view; B: head in frontal view; C: mesoscutum; D: propodeum; E: metasomal terga. 
rounded apex, with internal raised triangular area. Sterna 2-5 weakly tessellate, shiny, impunctate basally, finely punctate apically.

Male: Unknown.

Type material: Holotype female, Taliekekuotan, 2,300 $\mathrm{m}$, Baicheng County, Xinjiang Uygur Autn. Region, China, 5. vi. 1978 (X-z. Zhang); Paratypes: same locality as the holotype: 3 females, 8. vi. 1978 (X-z. Zhang); 3 females, 6. vi. 1978 (Y-h. Han); 1 female, Mt. Tomuerfeng, 3,200 m, Xinjiang, 10. vii. 1977 (C-j. Li).

Remarks: This species is similar to Andrena ruficrus Nylander in having the ferruginous hind tibiae and basitarsi, but can be separated from ruficrus in female by the clypeus more closely punctate, the labral process narrow, the less rugulated propodeal enclosure basally and the more hairy metasomal terga. Wu (1985) recorded this species as $A$. rufohospida Dours, but rufohispida was proposed as a subspecies of $A$. russula, which belongs to the subgenus Taeniandrena (Warncke, 1968).

Distribution: China (Xinjiang Uygur Autn. Region).

Floral association: Not available.

\section{Acknowledgments}

We indebted to Prof. Emeritus Y. Hirashima of Kyushu University and Prof. Yan-ru Wu of Institute of Zoology, Chinese Academy of Sciences, Beijing, China for their various help. We are grateful to Prof. Emeritus J. Yukawa of Kyushu University, Fukuoka for his support for this study and to Associate Prof. L. Westover of Kyushu University for reading the manuscript. The research was supported by the National Natural Science Foundation of China (No. 30970422) and Special Fund for Agroscientific Research in the Public Interest (No.201203080) to $\mathrm{H}-\mathrm{l} . \mathrm{Xu}$ and by the Environment Research and Technology Development Fund (S-9-2(8)) of the Ministry of the Environment, Japan to O. Tadauchi. This is a contribution from the Entomological Laboratory, Faculty of Agriculture, Kyushu University, Fukuoka (Ser.6, No. 112).

\section{References}

Ascher, J. and J. Pickering, 2011. https://amnh.discoverlife.org Grünwaldt, W., A. Z. Osytshnjuk, and E. Scheuchl, 2005. Neue Andrena-Arten aus der Paläarktis (Hymenoptera: Apidae: Andreninae). Entomofauna, 26(19): 346-368.

Gusenleitner, F. and M. Schwarz, 2002. Weltweite Checkliste der Bienengattung Andrena mit Bemerkungen und Ergänzungen $\mathrm{zu}$ paläarktischen Arten (Hymenoptera, Apidae, Andreninae, Andrena). Entomofauna, Suppl., 12:
1-1280 (in German).

Hedicke, H., 1933. Beiträge zur Systematic der Gattung Andrena F. (Hym. Apid.). Mitt. Zool. Mus. Berlin, 19: 199-220.

Hirashima, Y., 1957. Descriptions and records of bees of the genus Andrena from Eastern Asia. III (Hymenoptera, Andrenidae). Mushi, 30: 49-57.

Hirashima, Y., 1964. Systematic and biological studies of the family Andrenidae of Japan (Hymenoptera, Apoidea). Part 2. Systematics, 4. J. Fac. Agr., Kyushu Univ., 13 : 39-69.

Hirashima, Y., 1966. Systematic and biological studies of the family Andrenidae of Japan (Hymenoptera Apoidea). Part 2. Systematics 7. J. Fac. Agr., Kyushu Univ., 14: 89-131.

Lanham, U. N., 1949. A subgeneric classification of the New World bees of the genus Andrena. Univ. Calif. Press, Berkeley and Los Angeles.

LaBerge, W. E., 1964. Prodromus of American bees of the genus Andrena (Hymenoptera, Apoidea). Bull. Univ. Nebraska State Mus., 4(14): 279-316.

LaBerge, W. E., 1987. A revision of the bees of the genus Andrena of the Western Hemisphere. Part VII. Subgenera Euandrena. Trans. Amer. Ent. Soc., 101: 371-248.

Osytshnjuk, A. Z., 1995. Andrena. pp. 489-527. In P. A. Lehr (ed.). Key to the Insects of Russian Far East in Six Volumes. Vol. 4, Neuropteroidea, Mecoptera, Hymenoptera, Part 1. St. Petersburg, Nauka. (in Russian)

Peréz, J., 1905. Hyménoptères recueillis dans le Japon central, par M. Harmand, ministre plenipotentiaire de France àTokio. Bull. Mus. d'Hist. Nat., 11: 23-39, 79-87, 148-158.

Strand, E., 1915. Apidae von Tsingtao (Hym.). Ent. Mitt., 4: 62-78.

Tadauchi, O. and Y. Hirashima, 1987. Descriptions of two new species and one unrecorded female of the genus Andrena from Japan (Hymenoptera, Andrenidae). Esakia, (25): 133-139.

Tadauchi, O. and C. E. Lee, 1992. The family Andrenidae of Korea (Hymenoptera, Apoidea).1. Esakia, (32): 47-58.

Tamasawa, S. and Y. Hirashima, 1984. A new species of Andrena from Japan (Hymenoptera, Andrenidae). Esakia, (22): 103-105.

Warncke, K., 1968. Die Untergattungen der westpaläarktischen Bienen-gattung Andrena F. Mem. Est. Mus. Zool. Univ. Coimbra, (307): 1-111.

Wu, Y. R., 1982. Hymenoptera: Apoidea. pp. 379-426. In Huang, F.S. (ed.). Insects of Xizang Vol. II. Science Press, Beijing.

Wu, Y. R., 1985. Hymenoptera: Apoidea. pp. 137-150. Living Things of Tianshan Tumorfeng Region of Xinjiang". Xinjiang People Press, Wulumuqi.

Wu, Y. R., 1988. Hymenoptera: Apoidea. pp. 545-552. Insects of Mt. Namjagbarwa Region of Xizang. Science Press, Beijing.

$\mathrm{Xu}, \mathrm{H}-1$. and O. Tadauchi, 1998. Subgeneric positions and redescriptions of Strand's Chinese Andrena preserved in the German Entomological Institute (D.E.I., Eberswalde) (Hymenoptera: Andrenidae). Esakia, (38): 89-103.

Yasumatsu, K., 1940-41. A list of the Far Eastern species of the genus Andrena (Hym., Apoidea). Peking Nat. Hist. Bull., 15(4): 273-284. 